\title{
The Effect of Uncaria gambir Roxb. Extract on Superoxide Dismutase Activity in Proteinuric Wistar Rats Model
}

\author{
Rosmayanti Syafriani Siregar ${ }^{1} \mathbb{D},{\text { Aznan } \text { Lelo }^{2^{*}} \text { D, Delyuzar Haris }}^{3}$, Oke Rina Ramayani $^{1}$, Muhammad Ichwan ${ }^{2}$ D \\ ${ }^{1}$ Department of Pediatric, Faculty of Medicine, University Sumatera Utara, Medan, Indonesia; ${ }^{2}$ Department of Pharmacology \\ and Therapeutic, Faculty of Medicine, University Sumatera Utara, Medan, Indonesia; ${ }^{3}$ Department of Pathology Anatomy, \\ Faculty of Medicine, University Sumatera Utara, Medan, Indonesia
}

Edited by: Ksenija Bogoeva-Kostovska Citation: Siregar RS, Lelo A, Haris D, Ramayani OR, Ichwan M. The Effect of Uncaria gambir Roxb. Extract on Superoxide Dismutase Activity in Proteinuric Wistar Rats B):1505-1509. Keywro: : *Correspondence: Aznan Lelo, Department of Pharmacology and Therapeutic, Faculty of Medicine, Universitas Sumatera Utara, Medan, Indonesia. E-mail: aznanlelo@yahoo.com Received: 19-Sep-202 Revised: 10-Oct-2021 Copyright: @ 2021 Rosmayanti Syafriani Siregar Aznan Lelo, Delyuzar Haris, Oke Rina Ramayani,
Muhammad Ichwan Funding: This research was supported by TALENTA UN5.2.3.1/PPM/SPP-TALENTA/2020. UN5.2.3.1/PPM/SPP-TALENTA/2020
Competing Interests: The authors have declared that $n$. competing interests exist Open Access: This is an open-access article distributed under the terms of the Creative Commons Attribution-

\begin{abstract}
BACKGROUND: Nephrotic syndrome is a glomerular disease that is most often found in children with proteinuric as clinical manifestation. Gambier extract is a traditional medicine that has antioxidant effect. Its use to treat proteinuric has neve been done. Therefore, we conducted an analytical study on the effect of Gambier on proteinuric and superoxide dismutase (SOD) activity in proteinuric Wistar rat's model. This research is an experimental study with a post-test control group design. AIM: The aim is analyzing the effect of giving Gambier extract in decreasing urinary proteincreatinine ratio and increasing SOD activity.

METHODS: Male Wistar rats were given an injection of puromycin aminonucleoside $1.5 \mathrm{mg} / 100 \mathrm{~g}$ body weight (BW), subcutaneously for 5 consecutive days for being nephrosis. The experimental animals in this study were divided into four groups: $\mathrm{K} 1$, the control group, consists of group of rats that were injected with $0.15 \mathrm{ml} / 100 \mathrm{~g} \mathrm{BW}$ of aquabidest and not given Gambier extract. While K2 group consists of rats induced by puromycin and given $1 \mathrm{ml}$ of aquabidest, K3 consists of groups of rats induced by puromycin and then given Gambier extract $26 \mathrm{mg} / 200 \mathrm{~g}$ BW. Group K4 consists of rats induced by puromycin and then given $80 \mathrm{mg} / 200 \mathrm{~g} \mathrm{BW}$ of Gambier extract. The four groups were given treatment for 14 days, after which the rats were placed in a metabolic cage for $24 \mathrm{~h}$ to collect urine samples and then knocked down with ketamine for intracardiac blood collection.

RESULTS: The results of this study showed differences between the four groups of rats in terms of the mean urine protein/creatinine ratio $(p=0.015)$ and SOD activity $(p=0.036)$. Groups of rats that were given Gambier extracts 80 $\mathrm{mg} / 200 \mathrm{~g} \mathrm{BW}$ had lower urine protein/creatinine ratio and higher SOD activity.
\end{abstract}

CONCLUSION: Therapy of Gambier $80 \mathrm{mg} / 200 \mathrm{~g} \mathrm{BW}$ is better in managing proteinuric compared to $26 \mathrm{mg} / 200 \mathrm{~g}$.

\section{Introduction}

The mechanism of proteinuria occurred in idiopathic nephrotic syndrome (NS) is associated with immunological dysfunction. These resulted in the emergence of circulating factors that affect glomerular filtration passage permeability and damage podocyte. Oxidative stress which caused by imbalance of formation of free radical or reactive oxygen species (ROS) with antioxidants is also considered as one of the causes of the clinical disease manifestation, including the damage to the kidneys. Increased formation of ROS causes damage to cells due to lipids peroxidation that interferes the structure integrity of epithelial tubules cellular membrane, leading to increase of the glomerulus permeability, causing proteinuria [1]. Study by Duni et al. stated that the oxidative stress causes apoptosis of the podocytes and plays a role in the occurrence of fibrosis and glomerulosclerosis. Hence, antioxidants play a role in preventing the occurrence of proteinuric [2], [3].

Superoxide dismutase (SOD) is an antioxidant enzyme that is essential in defense against damage caused by free radicals [4]. This enzyme is an initial body defense against free radical derivative of oxygen. The main function of SOD is decomposition of superoxide into oxygen and hydrogen peroxide molecule in the cell. It consists of four classes, which are SOD Class I that requires manganese or $\mathrm{Fe}$ ions for catalysis (MnSOD and FeSOD) while Class II is an enzyme that depends on copper and zinc (CuZn-SOD) [5]. Study by Retnaningsih et al. showed that oxidative stress (hyperglycemia) in rats can decrease the activity of SOD and that antioxidants, derived from phenolic compounds of Koro Benguk seeds, can increase the antioxidant activity of SOD and reduce blood glucose levels [6]. Study by Kamireddy et al. proved that decrease in levels of SOD have been demonstrated in NS patients with severe proteinuria.

Gambier is a traditional medicinal plant widely available in Indonesia. Its active ingredients are in the form of catechins (phenolic compounds that are widely used as antioxidants, anti- inflammatory, and antimicrobial and several other uses in the field of medicine) [7]. Catechins are also found in fruits, green tea, black tea, and other medicinal plant. Study by Hase showed that by giving tea which contains catechins, there is a decrease of albumin 
excretion in diabetes-induced rats [8]. Other studies examine the effectiveness of catechins in Gambier extract, show that the Gambier dose of $26 \mathrm{mg} / 200 \mathrm{~g} \mathrm{BW}$ is able to inhibit liver fibrosis by lowering the levels of MDA and increase the antioxidant GSH enzyme [9]. Yunarto proved the effect of catechins from Gambier extract with a dose of $80 \mathrm{mg} / 200 \mathrm{~g} \mathrm{BW}$ provide antisclerotic effect on the aorta wall better than lower doses [10].

Thus, catechins are flavonoids with antioxidants effect and proved beneficial as antiproteinuria. Study on the effects of Gambier as antioxidant and antiproteinuria in NS patients had not been done although this is a new breakthrough in the field of pediatric nephrology. Hence, we did an analytical study about the effects of Gambier in decreasing protein and increasing SOD in Wistar rats' model.

\section{Methods}

To determine the effect of Gambier extract (Uncaria gambir Roxb) in proteinuria and level SOD, animal studies have been carried out. This study is pure experimental with post-test with control group design. The design is chosen because subjects and treatments are controllable, scalable, and reliable. In this study, we want to prove the effect of Gambier extract in decreasing urinary protein-creatinine ratio and increasing the activity of SOD in male Wistar rats which was given subcutaneous injection of puromycin aminonucleoside $1.5 \mathrm{mg} / 100 \mathrm{~g} \mathrm{BW}$ for 5 consecutive days. Due to the proteinuric effect of gambir extract based on alkaloids (catechins), the Gambier extract selected in this study consisted of $81.37 \%$ catechins.

Approval by the Ethical Research Committee of Faculty of Mathematics and Science is granted (No.00310/KEPH-Science/2020). Study was conducted at the Laboratory of Pharmacology, Faculty of Medicine Universitas Sumatera Utara, which are standardized and laboratory examination was conducted at the Integrated Laboratory, Faculty of Medicine Universitas Sumatera Utara.

Male Wistar rats were induced into having proteinuria by injecting puromycin aminonucleoside $1.5 \mathrm{mg} / 100 \mathrm{~g} \mathrm{BW}$ subcutaneously for 5 consecutive days, resulting in nephrosis [11]. Inclusion criteria include male Wistar rat, 8 weeks old, weight between 150 and $350 \mathrm{~g}$, healthy and active. Exclusion criteria are unhealthy rats due to infectious or non-infectious disease during clinical evaluation in appropriate environment conditions. Aggressive rats (attacking other rats) and rats which died during observation are considered as dropped out.

Animals of this study will be divided into four groups. K1, control group, consists of rats given aquabidest $0.15 \mathrm{ml} / 100 \mathrm{~g} \mathrm{BW}$ injection and later not given Gambier extract, but only given $1 \mathrm{ml}$ aquabidest. $\mathrm{K} 2$ is group of puromycin-induced rats at a dose of $1.5 \mathrm{mg} / 100 \mathrm{~g} \mathrm{BW}$ subcutaneously for 5 consecutive days and then given aquabidest $1 \mathrm{ml}$. $\mathrm{K} 3$ is group of puromycin-induced rats at a dose of $1.5 \mathrm{mg} / 100 \mathrm{~g} \mathrm{BW}$ subcutaneously for 5 consecutive days, then given $26 \mathrm{mg} / 200 \mathrm{~g} \mathrm{BW}$ Gambier extracts dissolved in $1 \mathrm{ml}$ aquabidest. $\mathrm{K} 4$ is group of puromycin-induced rats at a dose of $1.5 \mathrm{mg} / 100 \mathrm{~g} \mathrm{BW}$, then given $80 \mathrm{mg} / 200 \mathrm{~g} \mathrm{BW}$ Gambier extracts. All four groups were given treatment for 14 days, and on $14^{\text {th }}$ days, the rats were placed in metabolic cage for $24 \mathrm{~h}$ to take urine samples and then knocked down by ketamine to get sample of intracardiac blood. Rats were placed separately in cages measuring $30 \mathrm{~cm} \times 40 \mathrm{~cm} \times 15 \mathrm{~cm}$. Each treatment group was placed separately. At the bottom of the cage, a sterilized wooden husk mat was placed (replaced every 3 days or when it was dirty). Room temperature was maintained at $22-24^{\circ} \mathrm{C}$, with 12 light-dark cycle (the lights were switched on at 7 am and back off at $7 \mathrm{pm}$ ). Food given was CP552 (PT. Charoen Pokphand). Food was given ad libitum with an estimated $15-20 \%$ of body weight (BW), which is as much as $50 \mathrm{~g}$ per cage per day (Smith and Mangkoewidjojo, 1988). Water given was distilled water which was given ad libitum.

Male Wistar rats with appropriate age and BW were selected based on the inclusion and exclusion criteria. Induction into NS was done by giving puromycin aminonucleoside 1.5 mg/100 gr BW (Puromycin $®$ InvivoGen) subcutaneously for 5 consecutive days. Inoculation was done by positioning the tip of the needle pointing cranially, then the needle was inserted on the back of the rats by pinching the skin, and injection was done subcutaneously.

Gambier extract used was made by Sarie Uncariae (Toyo Brothers, PT) standardized procedure. Gambier extract was administered in two groups (K3 and K4). K3 group was given a dose of $26 \mathrm{mg} / 200 \mathrm{~g} \mathrm{BW}$ dissolved in $1 \mathrm{ml}$ aquabidest and was given orally through orogastric tube for 14 days. K4 was given 80 mg/200 g BW Gambier extract dissolved in $1 \mathrm{ml}$ aquabidest and was given orally through orogastric tube for 14 days.

After 14 days, urine and blood samples were taken. Urinary sample was taken by putting the rat in the metabolic cage for $24 \mathrm{~h}$ to get the $24 \mathrm{~h}$ urine. While on the metabolic cage, rats were still given food and water as usual. Blood sample was taken by intracardiac, after the rats were knocked down by ketamine injection intraperitoneally.

Proteinuria examination was carried out with Total Protein Colorimetric Assay Kit (Coomassie Brilliant Blue Method), Elabscience $®$. Fifty uL sample was mixed with a chromogenic agent. The examination procedure is by mixing all reagents and samples and then incubating the tube at room temperature for $10 \mathrm{~min}$. Then, the OD value was measured using a spectrophotometer based on the absorbance of $595 \mathrm{~nm}$. Proteinuria concentration results are expressed in $\mathrm{mg} / \mathrm{ml}$. 
Total SOD (T-SOD) activity was measured by T-SOD activity assay kit (hydroxylamine method), Elabscience ${ }^{\circledR}$. Superoxide anion free radicals are generated by the xanthine oxidase reaction system. If sample contained SOD, it can inhibit superoxide anion free radical. The inhibitory effect of SOD can reduce the formation of nitrite, resulting in the absorbance value of the sample tube become lower than the control tube. Add sample to reagent, stir with vortex mixer, incubate for $40 \mathrm{~min}$ at $37^{\circ} \mathrm{C}$. Then, add the chromogenic agent, stir, and leave it for $10 \mathrm{~min}$ in room temperature before measure the value of OD of each tube at $550 \mathrm{~nm}$. The results are calculated and expressed in $\mathrm{U} / \mathrm{ml}$.

Serum and urine creatinine examination was carried out with Creatinine $(\mathrm{Cr})$ Colorimetric Assay Kit (Sarcosine Oxidase Method, Elabscience ${ }^{\circledR}$ ). The examination was done by mixing $6 \mu \mathrm{L}$ of serum or urine samples into $180 \mu \mathrm{L}$ of reagent 1 (enzyme solution $\mathrm{A}$ ), then the samples were incubated for 5 min at temperature $37^{\circ} \mathrm{C}$. Then, added $60 \mathrm{~mL}$ reagent 2 (enzyme solution $\mathrm{B}$ ), incubated for $2 \mathrm{~min}$ at a temperature of $37^{\circ} \mathrm{C}$, then do examination on the long wave $515 \mathrm{~nm}$. Incubate at a temperature of $37^{\circ} \mathrm{C}$ for $3 \mathrm{~min}$ and measure the value of OD (A2) at $515 \mathrm{~nm}$. The sample concentration can be calculated by a formula based on the sample OD value and the result is expressed in $\mu \mathrm{mol} / \mathrm{L}$.

Urea (BUN) Colorimetric Assay Kit (Method Urease), Elabscience ${ }^{\circledR}$, was used to determine serum urea. Urea can be broken down into ammonia and carbon dioxide ions by urease. Ammonia ions can react with phenolic chromogenic substances and form a blue substance in an alkaline medium and the production of a blue substance is proportional to the urea content which can be calculated by a colorimetric test at $580 \mathrm{~nm}$. A $0.02 \mathrm{ml}$ sample was added to the EP tube, reagents were added and incubated before measuring the OD value of each tube with a $1 \mathrm{~cm}$ optical path cuvette at $580 \mathrm{~nm}$. The results obtained are then calculated and expressed in $\mathrm{mmol} / \mathrm{L}$.

The data obtained from the research results were analyzed, processed, and tabulated. The data are presented in the form of mean \pm standard deviation because it is distributed normally (confirmed by Shapiro-Wilk test). Tests comparing the levels of protein and SOD between the two groups of treatment were done using independent t-test. ANOVA was done to compare the four groups simultaneously.

\section{Results}

From the observations of the four groups of rats, there was no significant difference of the body weight and abdominal circumference on day 0 and 14 $(p>0.05)$. The mean results of the $24 \mathrm{~h}$ urine volume in day 14 were also not significantly different (Table 1).
Table 1: Demographic data of individual groups

\begin{tabular}{|c|c|c|c|c|}
\hline Variable & K1 & K2 & K3 & K4 \\
\hline $\begin{array}{l}\text { Body weight D-0 } \\
\text { Mean (SD) }\end{array}$ & 228.4 (27.98) & $231.8(17.77)$ & $224.3(26.93)$ & $242(16.35)$ \\
\hline $\begin{array}{l}\text { Body weight D-14 } \\
\text { Mean (SD) }\end{array}$ & 224.8 (28.31) & $235.6(27.98)$ & $212.8(35.47)$ & $232.8(8.96)$ \\
\hline $\begin{array}{l}\text { Abdominal } \\
\text { circumference D-0 } \\
\text { Mean (SD) }\end{array}$ & $13.8(0.55)$ & $13.9(0.38)$ & $13.6(0.61)$ & $13.8(0.42)$ \\
\hline $\begin{array}{l}\text { Abdominal } \\
\text { circumference D-14 } \\
\text { Mean (SD) }\end{array}$ & $13.7(0.44)$ & $14.1(0.26)$ & $13.6(0.75)$ & $14.2(0.27)$ \\
\hline $\begin{array}{l}\text { Urine volume } \\
\text { Mean (SD) }\end{array}$ & $9.33(1.42)$ & $18.41(1.51)$ & $9.90(7.21)$ & $13.33(7.23)$ \\
\hline
\end{tabular}

On day 14 , the rats were knocked down by ketamine intraperitoneal injection. Urine and serum examination was performed. Table 2 shows that there is no different among all four groups of rats in terms of serum protein, urea, and urine protein $(p>0.05)$, but there is different in the mean urine protein/creatinine ratio $(p=0.015)$.

Table 2: Serum protein and urea, urinary protein and creatinine, and urine protein-creatinine ratio data

\begin{tabular}{lllll}
\hline Variable & $\mathrm{K} 1$ & $\mathrm{~K} 2$ & $\mathrm{~K} 3$ & $\mathrm{~K} 4$ \\
\hline Serum protein $(\mathrm{mg} / \mathrm{mL})$ Mean $(\mathrm{SD})$ & $9.78(0.54)$ & $9.65(0.56)$ & $9.59(0.58)$ & $9.36(0.63)$ \\
Serum urea $(\mathrm{mmol} / \mathrm{L})$ Mean $(\mathrm{SD})$ & $6.72(1.46)$ & $6.73(2.52)$ & $6.26(0.93)$ & $4.64(0.73)$ \\
Proteinuria $(\mathrm{mg} / \mathrm{mL})$ Mean $(\mathrm{SD})$ & $0.36(0.27)$ & $0.33(0.37)$ & $0.77(0.22)$ & $0.36(0.20)$ \\
Urine creatinine $(\mathrm{Umol} / \mathrm{L})$ Mean $(\mathrm{SD})$ & $3.05(4.37)$ & $1.07(0.51)$ & $7.81(2.91)$ & $2.39(1.12)$ \\
Urine protein-creatinine ratio** & $0.12(0.01)$ & $0.33(0.15)$ & $0.10(0.02)$ & $0.15(0.02)$ \\
\hline${ }^{*}$ ANOVA test & & & &
\end{tabular}

The difference in mean protein/creatinine in each group is shown in Figure 1. Figure 1 shows that Gambier $80 \mathrm{mg} / 200 \mathrm{~g}$ BW has a better role for nephrosis compared to Gambier $26 \mathrm{mg} / 200 \mathrm{~g}$ BW. From Table 3, it can be concluded that there is a difference of the mean between the four groups $(p=0.036)$. This different is shown in Figure 2.

Table 3: SOD activity

\begin{tabular}{lllll}
\hline Group & $\mathrm{n}$ & \multicolumn{2}{l}{ SOD activity $($ Unit/ml) } & \multirow{2}{*}{ One-way ANOVA test } \\
\cline { 3 - 4 } & & Mean & SD & \\
\hline K1 & 5 & 76.06 & 7.6 & $\mathrm{~F}=3.855$ \\
K2 & 5 & 56.68 & 10.79 & $\mathrm{p}=0.036$ \\
K3 & 4 & 66.28 & 16.67 & \\
K4 & 5 & 79.62 & 10.25 & \\
\hline
\end{tabular}

\section{Discussion}

In this study, catechin contained in Gambier extract was given to determine its ability to counteract ROS caused by puromycin injection. In Group K4, SOD activity was increased significantly compared to K2. This proved the effect of prevention against ROS system. Decrease in SOD activity of $\mathrm{K} 2$ group compared with $\mathrm{K} 1$, $\mathrm{K} 3$, and $\mathrm{K} 4$, indicates that the SOD enzyme is needed to form $\mathrm{H}_{2} \mathrm{O}$ and $\mathrm{O}_{2}$. This function of SOD suggests its role in the removal of deleterious ROS from cellular environment [12]. Among many antioxidants, SOD is the one of antioxidants that work very fast in neutralizing various molecules that have the potential to become free radicals [4].

As shown previously, SOD is a strong antioxidant in the cell that inhibits ROS system. Study 


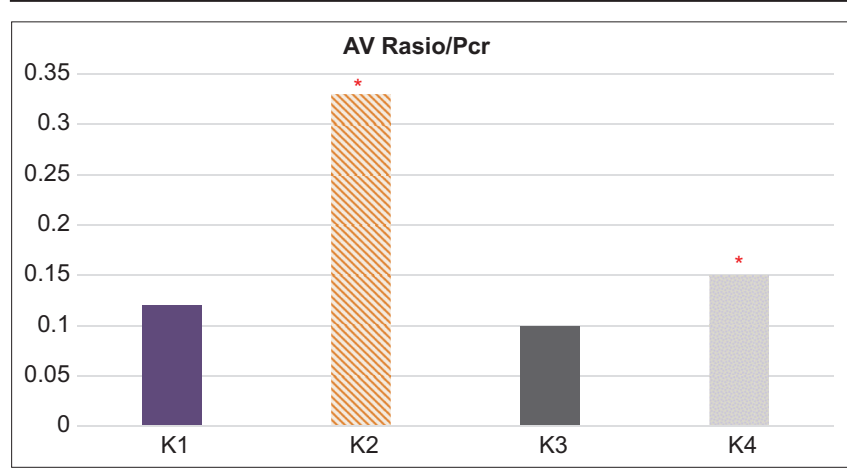

Figure 1: Mean urinary protein-creatinine ratio. K1 (Brown): Inj. $A q$ + P.O Aq (CTRL AQ), K2 (Green stripes): Inj.Puro + P.O Aqua (K(-)), K3 (Dark gray): Inj.Puro + P.O Gambir $26 \mathrm{mg} / 200 \mathrm{~g} \mathrm{BW}$ (P626), K4 (Yellow-gray dots): Inj. Puro + P.O Gambir 80 mg/200 $g B W(P 680),{ }^{*}$ Mean urinary protein-creatinine ratio (AVRasio/Pcr) different between Group K2 with K4: $p=0.05$

by Meng et al. found that the rats who suffered from kidney injury will experience a significant decrease of SOD activity in kidney medulla, evidenced by an increased excretion of urine protein [13]. There is not much different with this study which is probably made possible by puromycin (causing kidney injury in the form of proteinuric) and Gambier extract which can repair the kidney injury of rats with proteinuric. If the level SOD decline, the free radical formation increases so that adequate SOD supplementation is needed to protect the immune system and inhibit the development of disease [4].

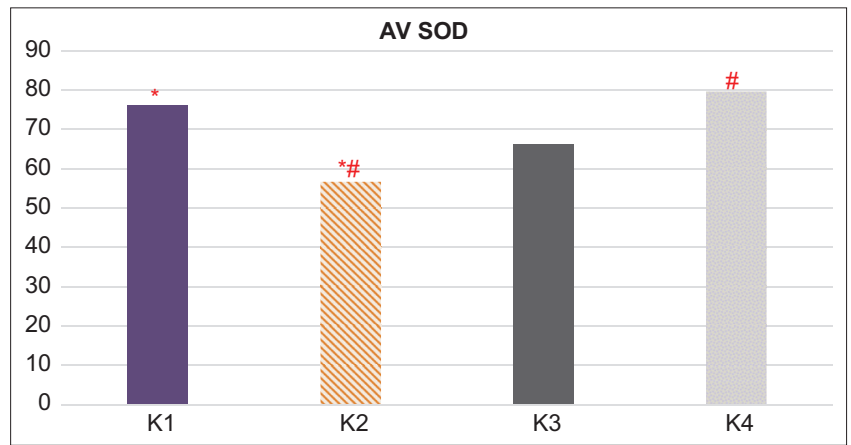

Figure 2: Mean differences of SOD between groups. K1 (Brown): Inj. $A q+$ P.O Aq (CTRL AQ), K2 (Green stripes): Inj. Puro + P.O Aqua (K(-)), K3 (Dark gray): Inj. Puro + P.O Gambir 26 mg/200 g BW (P626), K4 (Yellow-gray dots): Inj. Puro + P.O Gambir 80 mg/200 g BW (P680), *Different of mean (AV SOD) between $K 1$ and K2: $p=0.016$. \#Different of mean (AV SOD) between K2 and K4: $p=0.014$

Study by Tan concluded that SOD activity is decreased in rats with chronic kidney disease due to NS. Decreased of SOD activity demonstrated the role of SOD in inhibiting free radical in kidney because of proteinuria. Inhibition of free radical is very useful in the development of proteinuric renal disease and has become the basis of novel therapy for lowering proteinuric due to NS. Gambier extract acts as an inhibitor of free radical with catechin as the active substance, which will increase the SOD enzyme activity and reduce proteinuria [14]. Giving Gambier extract has also been shown to be able to protect the cell defense system again $\mathrm{O}_{2}^{-}$attack.

\section{Conclusion}

Gambier extract (U. gambir Roxb.) contributes in decreasing the urine protein-creatinine ratio in proteinuric model Wistar rats. Gambier extract (U. gambir Roxb.) has a role in increasing SOD activity in proteinuric model Wistar rats. The dose of Gambier extract that has better benefit in increasing SOD activity is $80 \mathrm{mg} / 200 \mathrm{~g} \mathrm{BW}$.

\section{References}

1. Kamireddy $R$, Kavuri S, Devi S, Vemula H, Chandana D, Harinarayanan S, et al. Oxidative stress in pediatric nephrotic syndrome. Clin Chim Acta. 2002;325(1-2):147-50. http://doi. org/10.1016/s0009-8981(02)00294-2

PMid:12367779

2. Duni A, Liakopoulos V, Roumeliotis S, Peschos D, Dounousi E. Oxidative stress in the pathogenesis and evolution of chronic kidney disease: Untangling ariadne's thread. Int J Mol Sci. 2019;20(15):1-17. http://doi.org/10.3390/ijms20153711 PMid:31362427

3. Jiang F, Liu GS, Dusting GJ, Chan EC. NADPH oxidasedependent redox signaling in TGF- $\beta$-mediated fibrotic responses. Redox Biol. 2014;2(1):267-72. http://doi. org/10.1016/j.redox.2014.01.012

PMid:24494202

4. Ighodaro OM, Akinloye OA. First line defence antioxidantssuperoxide dismutase (SOD), catalase (CAT) and glutathione peroxidase (GPX): Their fundamental role in the entire antioxidant defence grid. Alexandria J Med. 2018;54(4):287-93. https://doi.org/10.1016/j.ajme.2017.09.001

5. Ma X, Deng D, Chen W. Inhibitors and activators of SOD, GSH-Px, and CAT. Enzym Inhib Act. 2017;8:207-24. http:// do.org/10.5772/65936

6. Retnaningsih C, Darmono, Widianarko B, Muis SF. Increased superoxide dismutase antioxidant activity in hyperglycemia rat with Velvet Bean (Mucuna pruriens L). Agritech. 2013;33(2): 154-61. http://doi.org/10.22146/Agritech.9803

7. Ediningsih, Rahayuningsih S. Extraction, isolation, characterisation and antioxidant activity assay of catechin gambir (Uncaria gambir (hunter). Roxb. Alkimia. 2019;7(2): 177-88. http://doi.org/10.26656/fr.2017.3(1).097

8. Murase T, Haramizu S, Shimotoyodome A, Tokimitsu I, Hase T. Green tea extract improves running endurance in mice by stimulating lipid utilization during exercise. Am J Physiol. 2006;290(6):1550-6. http://doi.org/10.1152/ajpregu.00752.2005 PMid:16410398

9. Fahrudin F, Solihin Duryadi D, Kusumorini N, Ningsih S.The effectiveness of gambier extract (Uncaria gambir (Hunter) Roxb.) as hepatoprotective in rat (Rattus norvegicus L.) induced CCl4. J IImu Kefarmasian Indones. 2015;13(2):115-22.

10. Yunarto $\mathrm{N}$, Aini $\mathrm{N}$. Effect of purified gambier leaves extract to prevent atherosclerosis in rats. Health Sci J Indones. 2016;6(2):105-10. http://doi.org/10.22435/hsji. v6i2.4768.105-110

11. Shiiki H, Sasaki $Y$, Nishino T, Kimura T, Kurioka H, Fujimoto $S$, et al. Cell proliferation and apoptosis of the glomerular epithelial cells in rats with puromycin aminonucleoside nephrosis. Pathobiology. 1998;66(5):221-9. http://doi.org/10.1159/000028027 
PMid:9732237

12. Fattman CL, Schaefer LM, Oury TD. Extracellular superoxide dismutase in biology and medicine. Free Radic Biol Med. 2003;35(3):236-56. http://doi.org/10.1016/ s0891-5849(03)00275-2

PMid:12885586

13. Meng XM, Tang PMK, Li J, Lan HY. TGF-ß/Smad signaling in renal fibrosis. Front Physiol. 2015;6(3):82. https://doi. org/10.3389/fphys.2015.00082

PMid:25852569

14. Tan RJ, Zhou D, Xiao L, Zhou L, Li Y, Bastacky SI, et al. Extracellular superoxide dismutase protects against proteinuric kidney disease. J Am Soc Nephrol. 2015;26(10):2447-59. https://doi.org/10.1681/ASN.2014060613 